\title{
Corporate governance in het Verenigd Koninkrijk in beweging
}

\author{
Mr. H. Koster*
}

In deze column gaat de auteur in op het recente consultatiedocument van december 2017 met voorstellen voor aanpassing van de huidige UK Corporate Governance Code.

De eerste versie van de UK Corporate Governance Code, opgesteld door de Cadbury-commissie, verscheen in 1992. ${ }^{1}$ Deze 'Cadbury Code' wordt internationaal geduid als eerste toonaangevende code op het terrein van corporate governance. Sinds 1992 zijn er de nodige ontwikkelingen geweest op het gebied van corporate governance in het Verenigd Koninkrijk. De meest recente ontwikkeling is het in december 2017 door de Financial Reporting Council gepubliceerde consultatiedocument met voorstellen voor aanpassing van de huidige UK Corporate Governance Code. De consultatie liep in februari 2018 af. Dat corporate governance leeft in het Verenigd Koninkrijk blijkt uit het feit dat er meer dan 250 reacties op deze consultatie zijn ontvangen. De voorgestelde herziening van de UK Corporate Governance Code zal tot enkele belangrijke wijzigingen leiden. Ik zal hierna enkele van deze voorstellen kort aanstippen en deze spiegelen aan de huidige situatie in het Nederlandse bestel van corporate governance.

\section{Onafhankelijkheid non-executive director}

Een eerste bepaling die ik noem, is de voorgestelde provision 15, waarin staat dat een 'non-executive director' niet (langer) onafhankelijk is nadat deze non-executive director negen jaar in functie is geweest. ${ }^{2}$ De Nederlandse Corporate Governance Code kent een dergelijke bepaling niet. De huidige Nederlandse Code gaat uit van specifieke aanknopingspunten voor de bepaling wanneer geen sprake meer is van onafhankelijkheid. Voorbeelden zijn een commissaris die een aandelenpakket van ten minste $10 \%$ in de vennootschap houdt, of in de vijf jaar voorafgaand aan de benoeming werknemer of bestuurder van de vennootschap (inclusief gelieerde vennootschappen) is geweest, dan wel in het jaar voorafgaand aan de benoeming

\footnotetext{
Mr. H. Koster is verbonden aan Erasmus School of Law te Rotterdam.

1. De commissie was ingesteld door de Financial Reporting Council, de London Stock Exchange en de 'accountancy profession'.

2. Die 'negen jaar' wordt in het consultatiedocument als volgt gemotiveerd: 'While the current Code does not refer to tenure, we are aware that many companies and investors have used the "nine-year" criterion for independence as a "de facto" tenure period. This is the right approach, and in normal circumstances would not expect either an independent director or chair to be on a board for more than nine years in total, including in those circumstances where an independent non-executive goes on to be the chair.'
}

een belangrijke zakelijke relatie met de vennootschap of een aan haar gelieerde vennootschap heeft gehad. Voorts bepaalt de Nederlandse Code dat een commissaris wordt benoemd voor een periode van vier jaar en daarna éénmalig voor een periode van vier jaar kan worden herbenoemd, met dien verstande dat de commissaris nadien wederom kan worden herbenoemd voor een benoemingstermijn van twee jaar, die daarna met maximaal twee jaar kan worden verlengd. Herbenoeming na een periode van acht jaar moet worden gemotiveerd in het verslag van de raad van commissarissen ( $\mathrm{RvC})$. Ik meen dat voor deze suggestie over transformatie van onafhankelijkheid naar afhankelijkheid na ommekeer van een behoorlijk aantal jaren iets te zeggen valt. Voorstelbaar is dat commissarissen na negen jaar (meer) 'vergroeid' zullen zijn geraakt met de onderneming waar ze toezicht op houden. Voorts leidt een eindtermijn van onafhankelijkheid ertoe dat nog zorgvuldiger zal worden omgegaan met de optie voor een derde of zelfs vierde zittingstermijn van twee jaar.

\section{Interne auditfunctie}

In voorgesteld principe $\mathrm{L}$ wordt bepaald: 'The board should establish formal and transparent policies and procedures to ensure the independence and effectiveness of internal and external audit functions.' Die 'board' dient in het Verenigd Koninkrijk in meerderheid uit onafhankelijke 'non-executive board members' te bestaan. De auditcommissie is vervolgens op basis van provision 25 verantwoordelijk voor 'monitoring and reviewing the effectiveness of the company's internal audit function (...)'. In Nederland is op basis van principe 1.3 het bestuur verantwoordelijk voor de interne auditfunctie. De voorgestelde bepaling in het Verenigd Koninkrijk dat de 'executive en non-executive directors' maatregelen moeten treffen om de onafhankelijkheid en effectiviteit van de interne auditfunctie te waarborgen, lijkt mij ook voor de Nederlandse Code - dus bestuur en $\mathrm{RvC}$ tezamen - een waardevolle aanvulling. Daarnaast zou mijns inziens ook in Nederland kunnen worden overwogen om de interne auditfunctie onder de $\mathrm{RvC}$ te laten vallen en de auditcommissie als eerste aanspreek- 


\section{Maandblad}

Ondernemingsrecht

punt aan te wijzen voor de reguliere werkzaamheden van de interne auditfunctie. ${ }^{3}$

\section{Diversiteit}

Op basis van het voorgestelde principe J dienen 'board appointments (...) be based on merit and objective criteria, and promote diversity of gender, social and ethnic backgrounds, cognitive and personal strengths'. De Nederlandse Code gaat minder ver en rept over de $\mathrm{RvC}$ die een diversiteitsbeleid opstelt voor de samenstelling van het bestuur, de RvC en, indien aanwezig, het executive committee. In dat beleid moet worden ingegaan op de concrete doelstellingen ten aanzien van diversiteit en de voor de vennootschap relevante aspecten van diversiteit, zoals nationaliteit, leeftijd, geslacht en achtergrond inzake opleiding en beroepservaring. Ook over deze bepaling - maar waarschijnlijk nog veel belangrijker: de invulling in de praktijk - zou nog eens kritisch kunnen worden nagedacht.

\section{'Contribute to wider society'}

Ten slotte, opmerkelijk gelet op het idee van 'shareholder primacy' dat in het Verenigd Koninkrijk altijd als leer werd aangehangen, is het bepaalde in voorgesteld principe A, dat '[a] successful company is led by an effective and entrepreneurial board, whose function is to promote the long-term sustainable success of the company, generate value for shareholders and contribute to wider society'. Dit voorstel is zelfs al als 'radical' en 'terrific' bestempeld. ${ }^{4}$ Wat dit principe A precies inhoudt, valt nu nog niet te zeggen, maar wel heeft het er schijn van dat invloed van 'shareholder primacy' hiermee wat lijkt af te nemen. ${ }^{5}$ In principe 1.1 van de Nederlandse Code komen we overigens een enigszins vergelijkbare omschrijving tegen: 'Het bestuur richt zich op de lange termijn waardecreatie van de vennootschap en de met haar verbonden onderneming en weegt daartoe de in aanmerking komende belangen van de stakeholders.' Evenals in het voorstel in het Verenigd Koninkrijk zou in de Nederlandse Code het woord 'duurzaam' nog kunnen worden toegevoegd.

Ik rond af. De Britse voorstellen laten zien dat het denken over corporate governance nooit stilstaat. Het is interessant om te bespeuren dat bepaalde uitgangspunten die al sinds de Cadbury Code aan het Britse bestel van corporate governance ten grondslag liggen nu - voorzichtig - ter discussie lijken te worden gesteld. Hoe dan ook, Nederland kan zonder meer

3. Dit ook omdat als er een risicomanagementfunctie en/of compliancefunctie is die direct of indirect aan het bestuur rapporteert, het niet voor de hand ligt dat de interne auditfunctie ook aan het bestuur rapporteert, onder meer omdat de interne auditfunctie een oordeel moet geven over de kwaliteit van risicomanagementprocessen en het verschaffen van assurance dat risico's correct worden geëvalueerd.

4. Five issues in UK's corporate governance revamp, Financial Times 7 maart 1018.

5. Voorts wijs ik ook op hetgeen in provision 3 wordt voorgesteld, te weten: 'The board should establish a method for gathering the views of the workforce. This would normally be a director appointed from the workforce, a formal workforce advisory panel or a designated non-executive director.' zijn voordeel doen met deze discussie, het is immers van groot belang dat de Nederlandse Code evenals de Britse code relevant en actueel blijft en meeademt met de tijdgeest. 